\title{
War Invalids and Disabled Soldiers in the Habsburg Army: The Case of the Djurdjevac Regiment in 1860/61
}

\author{
Ivana Horbec ${ }^{1}$ (D), Dubravko Habek ${ }^{2,3}$ \\ ${ }^{1}$ Croatian Institute of History, Zagreb, Croatia \\ ${ }^{2}$ University Department of Obstetrics and Gynecology Clinical Hospital "Sveti Duh", Zagreb, \\ ${ }^{3}$ Croatian Catholic University, Zagreb, Croatia
}

\begin{abstract}
:
Soldiers of the Military Frontier fought numerous wars for the Habsburg Monarchy from the 16th to the 19th century. By the nature of their service they were susceptible to injuries and health difficulties that limited their ability to perform the service. The aim of this research was to analyse health conditions and most represented illnesses of Frontiersmen in the second part of the 19th century, as well as the Habsburg policy towards disabled soldiers and war invalids. The analysis is based on the case report and findings of the General Arbitration Commission of the Varaždin general command for the Đurđevac regiment in the military year 1860/61, kept in the Austrian State Archives.
\end{abstract}

KEYWORDS: Invalids, Habsburgs Army, Military Frontier, medicine, medicohistoriography

\section{SAŽETAK:}

RATNI INVALIDI I VOJNICI $S$ INVALIDITETOM U HABSBURŠKOJ VOJSCI: PRIKAZ ĐURĐEVAČKE PUKOVNIJE I860/6I.

Vojnici Vojne krajine borili su se za Habsburšku Monarhiju u brojnim ratovima od 16. do 19. stoljeća. Po prirodi svoje službe bili su podložni ozljedama i zdravstvenim tegobama koje su ograničavale njihovo ispunjavanje službe. Cilj ovog istraživanja bila je analiza zdravstvenog stanja i najzastupljenijih bolesti u Graničara u drugoj polovici 19. stoljeća te habsburšku politiku prema vojnim invalidima i onesposobljenim vojnicima. Analiza se temelji na prikazima slučajeva i nalazima Generalne arbitrarne komisije varaždinske generalkomande za Đurđevačku regimentu u vojnoj godini 1860./61., koji se čuvaju u Austrijskom državnom arhivu.

KLJUČNE RIJEČI: Invalidi, Habsbruška vojska, Vojna krajina, Medicina, Medicinska historiografija

OPEN ACCESS

Correspondence: Ivana Horbec PhD ihorbec@isp.hr orcid.org/0000-0002-4898-2555

This article was submitted to RAD CASA - Medical Sciences as the Essay

Conflict of Interest Statement: The authors declare that the research was conducted in the absence of any commercial or financial relationships that could be construed as a potential conflict of interest.

Received: 28 August 2019 Accepted: 27 October 2019 Published: 17 December 2019

Citation:

Hrobec I and Habek D. War Invalids and Disabled Soldiers in the Habsburg Army: The Case of the Djurdjevac Regiment in 1860/61. RAD CASA - Medical Sciences. $540=48-49$ (2019): 86-91. https:// 540-48-49 (2019): 86-91. https://

Copyright (C) 2019 Horbec and Habek.This is an open-access article distributed under the terms of the Creative Commons Attribution $\mathrm{Li}$ cense (CC BY). The use, distribution or reproduction in other forums is permitted, provided the original au thor(s) and the copyright owners(s) are credited and that the original publication in this journal is cited, in accordance whit accepted adacemic accordance whit accepted adacemic
practice. No use, distribution or repractice. No use, distribution or re-
production is permitted which does not comply with these terms. 
Introduction: The Habsburg Monarchy and its FrontiersMEN

The Military Frontier (Military Border, Germ. Militärgrenze) acted as a special military region along the eastern borders of the Habsburg Monarchy with the Ottoman Empire throughout the Early Modern Period up until its abolition in $1873 / 1881$. As a territory with its own administrative, judicial and financial structure, the Frontier was crucial for the subsistence of the Habsburg Monarchy, as well as for the continuous existence of a stable military force. The population of the Military Frontier - known as the Frontiersmen (Germ. Grenzer) undertook to defend the Monarchy in return for the land they were granted by the Habsburgs. Every grown man was therefore subject to military service for the Monarchy.

Governed directly from the Court of Vienna, i.e. the Viennese Court War Council (Hofkriegsrat), the Frontier was constantly reorganised and subject to numerous ordinances so as to keep the functionality in line with contemporary principles of warfare and public administration. At the end of the $17^{\text {th }}$ century, following the Treaty of Karlowitz (1699) between the Habsburg Monarchy and the Ottoman Empire, the territory of the Military Frontier expanded towards the East and settled along the rivers of Danube and Sava, as well as in the eastern parts of the Banat of Temeswar so as to include parts of present-day Croatia, Serbia, Romania and Hungary. In the mid-18th century the Military Frontier was finally modelled after the regular regiments of the Habsburg army, with the difference that the Frontier's general commands and regiments also served as administrative units until the second part of the $19^{\text {th }}$ century. In Croatian lands under the Habsburg rule, the Frontier consisted of four general-commands (for Slavonia, Varaždin area, Ban's Frontier and Karlovac area), subdivided into altogether 11 regiments. The Slavonian general command consisted of three regiments (Gradiška, Brod, Petrovaradin); General command of the Varaždin area of two regiments (Đurđevac, Križevci); Ban's Frontier also of two regiments (Glina, Petrinja) and Karlovac general command of four regiments (Gospić, Lika, Otočac, Slunj) ${ }^{1-7}$ (for administrative division of the land cf. Map 1).

The Grenzers fought numerous wars led by the Habsburgs from the 16th to the $19^{\text {th }}$ century - not only the Ottoman wars at the eastern borders of the Monarchy, but also, especially from the $18^{\text {th }}$ century on, the European wars Habsburgs led with Prussia, France or Russia. Since the Thirty Years' War (1618-1648) they gained a significant reputation in contemporary warfare ${ }^{8,9}$. However, the Grenzers were by the nature of their service also susceptible to health difficulties in performing the service. War invalids and disabled soldiers were so common in the Military Frontier that the Habsburg administration had taken a particular account on how to register or treat and reward these subjects, or even to restrict the burden they created to the society.

This paper aims to illustrate the Vienna Court's policy towards the disabled soldiers of the Military Frontier in the second half of the $19^{\text {th }}$ century - in a time when a solid structure of the Frontier was set and the policy towards the disabled soldiers was firmly adopted. Our research relates to 348 disabled soldiers from a regiment of Đurđevac in Varaždin general command during the military year $1860 / 61$. Relating to the overall policy of the Court of Vienna towards the disabled soldiers in the Habsburg Monarchy since 1750s, the procedures adopted by the Habsburg army will be analysed, as well as the health condition of the soldiers in relation to their age and service time in the army. The paper also aims to contribute to the knowledge of the major illnesses that affected the soldiers of the Military Frontier in the second half of the 19th century, as well as to the understanding of the state-controlled treatment of such individuals.

MEASURES OF STATE CARE TOWARDS DiSABLED SOLDIERS IN THE HABSBURG MONARCHY

Since the second half of the 18th century, supported by the ideas of the Enlightenment, significant progress was achieved in the Habsburg Monarchy in the development of the public health care system ${ }^{10}$. Habsburg rulers and political centres of power in Vienna turned their attention to the social role of the state: active participation of the ruler and his institutions in regulating major social systems - as was the public health care - was defined as his duty, and an object of the state's field of interest (political issue, or politicum). That resulted with designing a stable, (proto)modern system of a public health care in all provinces of the Habsburg Monarchy ${ }^{11}$, as well as with the foundation for all future regulations respecting current trends in the institutional approach to the public health care system. One of the major turning points in designing a stable, proto-modern system of public health care was the 1770 General Norm in Health Care Issues, the basic piece of legislation regulating the public health care system in the Habsburg Monarchy (Sanitätsund Kontumazordnung; Generale normativum in re sanitatis) ${ }^{11,12}$. With this ordinance, a network of institutions was set up dedicated to the health care, with the new health care system being subordinated to the Habsburg ruler and exempt from the local spheres of influences. The expansion of the network of medical educational institutions - from the Medical School of the University of Vienna to the specialized institutions, as was the Josephinum, a non-university academy primarily designed for training of military surgeons - had the decisive influence on the improvement of medical services and the further professionalization of medical professions ${ }^{10,11,13}$. Educated medical practitioners were granted the exclusive right to practice medicine, replacing all other competing providers of health care services (as clergy, quacks, herbalists and others): they became public servants, subject to state regulations.

Directly controlled by the Court of Vienna, the Military Frontier was a front-runner in implementing new health care standards and state ordinances. As early as the 1730s a Sanitary cordon was established as part of the Military Frontier on the eastern borders of the Monarchy, whose purpose was permanent anti-epidemic protection 


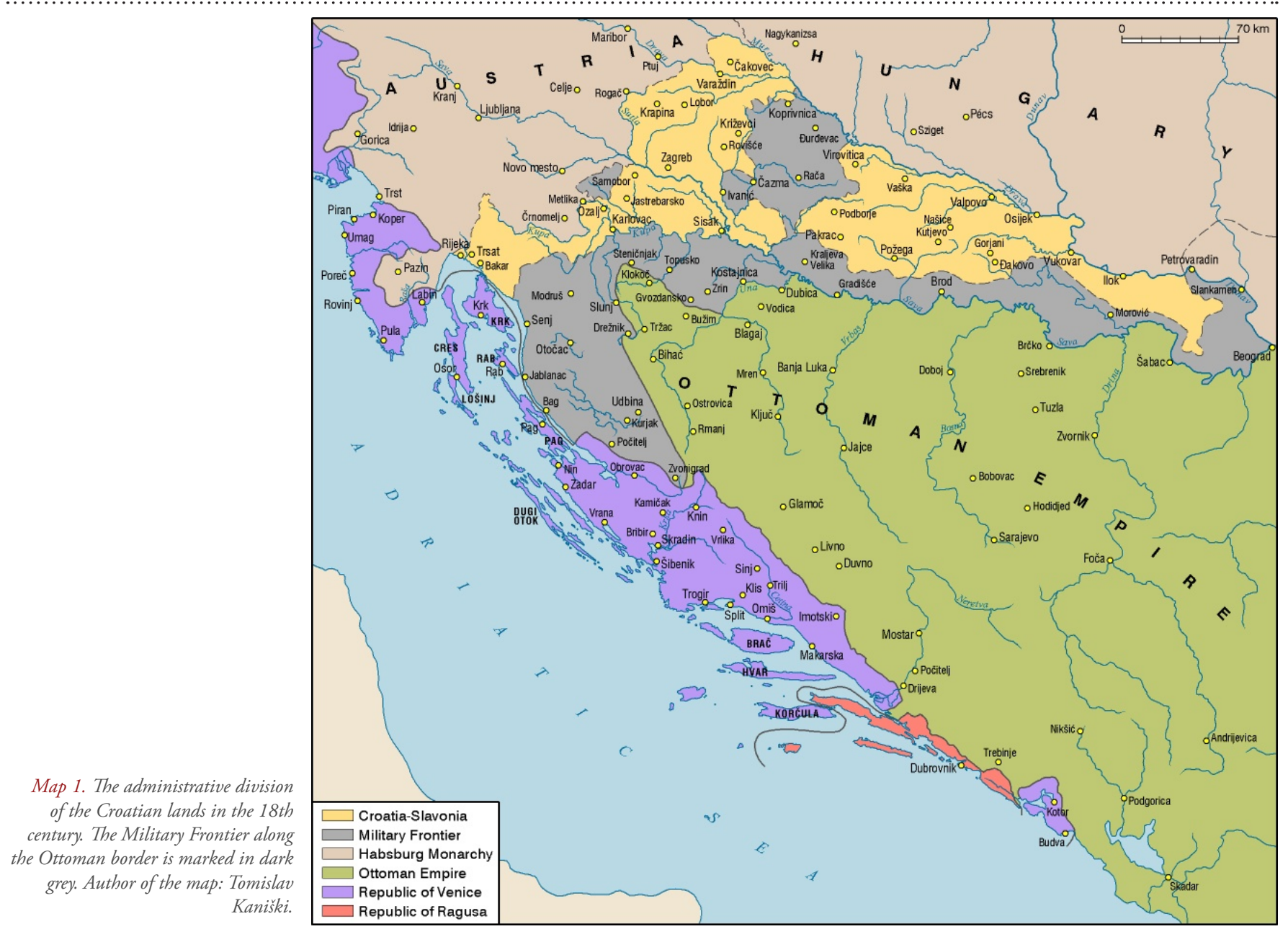

of both of the Monarchy and entire Central Europe ${ }^{11,14}$. The number of medical personnel in the Frontier was much higher in comparison to the civil parts of the Monarchy (with only exception of the bigger cities). Every regiment of the Frontier had medical stationaries with military hospitals, pharmacies, several physicians and a dozen of military surgeons and midwives entrusted with the health care in companies. According to the Systematic regulation from 1800 (Systemalverordnung), each regiment had to have a physician in charge for the health care in the regiment (Regimentsartzt), two senior physicians (Oberartzt), four senior military surgeons (Oberwundartzt) and a major number of lower physicians and military surgeons, employed at the companies. The supreme control over the health care in the Frontier was exercised by the main military physician stationed in the headquarters in Zagreb ${ }^{15}$. This medical team was also responsible for detecting disabled soldiers and estimating their health conditions. It also provided an expert opinion on further treatment of these individuals.

An existence of a systematic state care for military invalids and disabled soldiers could be traced to the mid-18th century, when first institutional infrastructure aimed at facilitating self-sustainability of military invalids and disabled soldiers could be found, followed by a series of state ordinances and provisions of the Court War Council. The foundation of the Court Commission for the Invalids (Invalidenhofkommission) in 1750/51 as an independent Court institution could be singled out as a turning point in making of the ruler's strategy towards the military invalids and disabled soldiers ${ }^{16}$. The Commission consisted of representatives from several institutions from the already mentioned Court War Council, then the General War Commissariat (Generalkriegskommissariat), which was technically a sub-department of a General War Council responsible for the economics of the Habsburg military organisations, a Directorium in publicis and cameralibus, a massive executive body of the supreme state administration in that period, Chancelleries of specific lands of the Monarchy etc. The Commission for the Invalids joined the Directorium in 1757 and the General War Commissariat in 1762, and was re-established as an independent Court institution under the name Department for Invalids (Invalidenamt). It was abolished in 1803, handing its agenda to the Court War Council. In larger cities the "Houses for military invalids" (Militärinvalidenhaus) were build aimed to take care for the war veterans and serving as almshouses. Also the legislation went in line with the institutional establishment: for example, it was ordained on August $5^{\text {th }} 1750$ that disabled individuals should have priority in gaining the apprenticeships at craftsmen ${ }^{17}$, and in 1759 the continuous financial help from military financial offices for disabled soldiers not admitted to the Invalidenhaus was established ${ }^{18}$. Since the second half of the 18 th century, the donations to the foundation for the disabled soldiers were also encouraged $^{19}$. On the other hand, disabled soldiers faced significant constrains in their public life: for example, the beggary was forbidden to them and military authority were obliged to keep the record of the soldiers who started such practice and to direct them to the Houses for military invalids ${ }^{17}$, and they were allowed to marry only under the condition the marriage would be approved by the Department for Invalids as a means of improving their condition - because their eventual offspring was estimated by the legislator as "more damaging than useful to the state".

According to the 1807 General Law of the Military Border (Grundgesetze für die Carldstädter, Warasdiner, Banal-, Slawonische und Banatische Militärgrenze) all military invalids were exempt from labour services ${ }^{21}$. The substantial care for the military invalids was encouraged by the local authorities too: for example, the Croatian Parliament asked from the Court of Vienna to grant more appro- 
priate support for the disabled Grenzers "that have long served"23. The establishment of foundations for financial support of disabled soldiers and their families is also mentioned in $19^{\text {th }}$-century sources: one foundation was, for example, established by the Administrative Commission in Vienna after the wars against the Napoleon in 1815, aiming to help the wounded soldiers of the Đurđevac regiment. This foundation was additionally confirmed by the "Statute of Governor Jelačićs Foundation for invalid soldiers" on 24. November $1850^{24}$. Towards, and during the $19^{\text {th }}$ century, the Court War Council issued a number of ordinances related to the ascertaining of the disability of such subjects, as well as their treatment and classification. As the most important for $19^{\text {th }}$-century practice, the ordinances of March $29^{\text {th }}$ and June $23^{\text {rd }} 1777$ and the provisions of November 11th 1800 , December $26^{\text {st }} 1801$ and November $15^{\text {th }} 1808$ could be singled out $^{25}$. Special revisions made by the corps of officers and brigadiers were also established, in order to inspect the health conditions of Grenzers in military units and determine their capacity for military service. The General Arbitration Commissions (Superarbitrierungscommission), that existed at every general command, inspected their findings and proposed the treatment and classification to the Court War Council. They were empowered for the inspection only of the military personnel serving in the regiments under their jurisdiction.

\section{A "Nominal List" of disabled soldiers for the Đurøevac} REGIMENT IN THE MILITARY YEAR 1860/61

The number of war invalids and disabled soldiers depended, of course, on activity of the Habsburg army and the Grenzers' participation in war operations. During the wars their share in the adult male population of the Frontier could rise up to $75 \%$, with "full invalids" building up to the $31 \%$ of the adult male population ${ }^{3}$. According to Karl Bernard von Hietzinger and his "Statistics of the Military Frontier" from 1817-1823, every $16^{\text {th }}$ soldier from the Ban's general command was found temporary disabled for military service due to his health conditions, as well as every $14^{\text {th }}$ soldier of the Karlovac general command or every $17^{\text {th }}$ soldier from Varaždin general command ${ }^{27}$.

Disabled soldiers and military invalids were classified by the General Arbitration Commissions as the "full invalids" (Realinvalid), "half-invalids" (Halbinvalid) and "temporary disabled" (Zeitinvalid). According to the agreed classification, "full invalids" were individuals with incurable health issues, who were permanently incapable of military service, yet still capable of "light" services, as, for example, in military hospitals. The classification "half-invalids" related to the Grenzers who were, due to their health issues, permanently incapable for warfare, but were still capable of other services in the Military Frontier. "Temporary disabled" were individuals who were temporarily unfit for military service due to their health conditions, but could eventually be healed and again capable for military service ${ }^{25}$. Such list of disabled Grenzers were prepared by the corps of officers and brigadiers, and served for the General Arbitration Commission to organize a check-up and to provide an opinion for the Court War
Table 1. The illnesses of the soldiers diagnosed in the regiment of Đurdevac in Varaždin general command in the military year 1860/61

\begin{tabular}{|l|c|}
\hline Diagnosis & Nr. of soldiers \\
\hline $\begin{array}{l}\text { Amputations and wounds } \\
\text { with neurological and } \\
\text { orthopedic sequelae }\end{array}$ & 60 \\
\hline $\begin{array}{l}\text { Chronic respiratory } \\
\text { obstructive diseases }\end{array}$ & 51 \\
\hline Orthopaedic deformities and \\
anomalies
\end{tabular}

Council on the classification of the individual soldier, his health conditions and future assignments in the Military Frontier.

Some of the rare preserved sources could point to the extent on how these regulations were adapted in practice. Our research was focused on the case report made by the General Arbitration Commission for soldiers serving in the Regiment of Đurđevac in Varaždin General Command in the military year $1860 / 61^{28}$. The report was signed by Dr Matzner, head physician of the Varaždin General Command. According to the command of the Court War Council from May $2^{\text {nd }} 1862$, the Regiment of Đurdevac conducted a record of health conditions of all active soldiers serving in the regiment. The total of 348 soldiers were found unfit for the military service and were demobilised in the military year $1860 / 61$. That number related to proximately $5 \%$ of the adult male population of the regiment. The results of the investigation were submitted to the General Arbitration Commission of the Varaždin general command in May 1862. The Commission called all of the 348 men for a check-up and made a report on the Court War Council, suggesting the classification and treatment of these subjects. 24 of them were found fitting for the military service again. Nine of them were classified as "temporary 
disabled", whose recovery was soon to be expected. 22 men were classified as "half-invalids", and four men were sent to a health resort of Topusko in the Ban's general command for recovery. One man was sent to the hospital for further check-up, and altogether 21 men did not respond to the call due to their illness or other reasons. Seven people died during the process. Others $(248 \mathrm{men})$ were proclaimed "full invalids" and not capable for further military service.

The disabled soldiers were 20 to 34 years old and served in the military from 5 months to 16 years until their disability. According to the findings of the General Arbitration Commission of the Varaždin general command, most of the disabled soldiers (60 cases) were diagnosed with conditions from amputations and wounds with neurological and orthopedic sequelae (neuralgia, paresis, limb shortening or amputees). In 39 cases orthopaedic deformities and anomalies were diagnosed. Chronic respiratory obstructive diseases (asthma, emphysema) were reported in 51 patients, while tuberculosis was diagnosed for 23 patients. 20 soldiers were diagnosed with hernia and hydrocele, while poor eyesight and other eye diseases (trachoma) was found in 18 examined soldiers. Probably due to malnutrition, 18 inspected soldiers were diagnosed with weakness and infirmity. Furthermore, skin diseases (scrofula, ulcer) were diagnosed for 16 examined soldiers, rheumatism for 12 soldiers, heart and spleen diseases for 11 soldiers, deafness and ear diseases for 10 soldiers, psychiatric diseases for eight soldiers. Finally, seven of the examined soldiers had gout, two epilepsy, three goiter, one baldness, one tooth decay and one scorbut (Table 1).
The beginning of the second half of the $19^{\text {th }}$ century was an era of then-incurable infectious diseases, such as tuberculosis, which had a natural course but with high morbidity and complications, up to high mortality. Only then will infectious agents of infectious diseases slowly begin to be discovered and disinfection and antisepsis put into operation, still far from the discovery of chemotherapeutics and antibiotics.

The above diagnoses and the morbidity among the male population are typical for the pathology for the time. The results could be compared to the data of hospitalized patients at the Zagreb Foundation Hospital in 1839, presented by Lujo Thaller ${ }^{29}$. Mostly the infectious diseases were diagnosed: recurrent fever and sexually transmitted diseases (lues, gonorrhea), as well as diarrhea, itch and tuberculosis, followed by chronic dementia, gout or meningitis. According to our own research of the hospitalized patients in the military hospital (Garnisonsspital) in Bjelovar in the beginning of the second half of the $19^{\text {th }}$ century, the most common cause of death was tuberculosis in $19.7 \%$, hydrops in $16.4 \%$, pneumonia $10.5 \%$, typhus $5.9 \%$ and febris nervosa in $4.8 \%{ }^{30}$.

\section{LITERATURE:}

1. Moačanin F, Valentić V. Vojna Krajina u Hrvatskoj, Zagreb: Povijesni muzej Hrvatske, 1981.

2. Valentić V. Vojna krajina i pitanje njezina sjedinjenja s Hrvatskom, Zagreb, 1981

3. Roksandić D. Vojna Hrvatska - La Croatie Militaire. Krajiško društvo u Francuskom carstvu, sv. 1, Zagreb: Školska knjiga, 1988. 4. Buczynski A. Gradovi Vojne krajine, II vols, Zagreb, 1997.

5. Kaser K. Freier Bauer und Soldat: die Militarisierung der agrarischen Gesellschaft an der kroatisch-slawonischen Militärgrenze (15351881), Wien-Köln-Weimar: Böhlau, 1997.

6. Štefanec N. Država ili ne. Ustroj Vojne krajine 1578. godine i hrvatsko-slavonski staleži u regionalnoj obrani i politici, Srednja Europa, Zagreb 2011.

7. Roksandić D, Milković Šarić K (eds.), Vojna krajina u suvremenoj historiografiji, Zagreb, FF Press, 2012.

8. Brnardić V. Imperial Armies of the Thirty Year's War: Infantry and Artillery. Oxford: Osprey Publishing, 2009.

9. Brnardić V. Imperial Armies of the Thirty Year's War: Cavarly. Oxford: Osprey Publishing, 2010.

10. Spary EC. "Introduction: Centre and periphery in the eighteenth-century Habsburg 'medical empire'", Studies in History and Philosophy of Biological and Biomedical Sciences 43 (2012), 684-690. 11. Horbec I. Zdravlje naroda - bogatstvo države. Prosvijećeni apsolutizam i počeci sustava javnoga zdravstva u Hrvatskoj. Zagreb, 2015. 12. Supplementum Codicis Austriaci, oder Chronologische Sam- mlung aller vom 1ten Jänner 1759 bis letzten Dezember 1770

[...] erlassenen Generalien, Patenten, Satzordnungen, Rescriptem, Resolutionen, dann Landesobrichkeitlichen Edikten, Mandaten und Dekreten, part VI., Vienna 1777, pp. 1247-1298.

13. Broman TH. The Transformation of German Academic Medicine, Cambridge University Press, 1996.

14. Vodopija J (ed.), Sanitarni kordon nekad i danas. Zbornik radova Simpozija odr\#anog u povodu 250-te obljetnice Sanitarnog kordona. Zagreb: Interpublic, 1978.

15. Bazala V. Poviestni razvoj medicine u hrvatskim zemljama, Zagreb, 1943.

16. Walter F. Die österreichische Zentralverwaltung, Vol II: Von der Vereinigung der Österreichischen und Böhmischen Hofkanzlei bis zur Errichtung der Ministerialverfassung (1749-1848). Part I/I: Die Geschichte der österreichischen Zentralverwaltung in der Zeit Maria Theresias (1740-1780). Wien, 1938.

17. Joseph Kropatschek, ed.] Sammlung aller k. k. Verordnungen und Gesetze vom Jahre 1740 bis 1780 [...], Vol. I. Wien 1786.

18. Joseph Kropatschek, ed.] Sammlung aller k. k. Verordnungen und Gesetze vom Jahre 1740 bis 1780 [...], Vol. III. Wien 1786.

19. Joseph Kropatschek, ed.] Sammlung aller k. k. Verordnungen und Gesetze vom Jahre 1740 bis 1780 [...], Vol. VII. Wien 1787.

20. Joseph Kropatschek, ed.] Sammlung aller k. k. Verordnungen und Gesetze vom Jahre 1740 bis 1780 [...], Vol. VI. Wien 1786.

21. Milković K. "Položaj časnika prema zakonskoj regulativi za Vojnu krajinu: Krajiška prava (1754.) i Osnovni krajiški zakon (1807.), 
Povijesni prilozi 31 (2006), pp. 161.-182.

22. Roksandić D. Vojna Hrvatska - La Croatie Militaire. Krajiško društvo u Francuskom carstvu, sv. 1, Zagreb: Školska knjiga, 1988.

23. Čepulo D, Krešić M, Hlavacka M, Reiter I (eds.) Croatian, Slovenian and Czech Constitutional Documents 1818-1849. Berlin, New York: De Gruyter, 2010.

24. Statuten des Ban Jellačić-Invalides Fondes. Agram, National Buchdruckerei des Dr. Ljudevit Gaj, 1850. Croatian State Archives in Zagreb (Hrvatski državni arhiv Zagreb), holdings Zagreb General Command (Zagrebačka Generalkomanda), box 12, R 6-1850.

25. von Bundschuh C (ed.), Uibersicht das bey der k. k. österreichischen Armee bestehenden Militär-Oeconomie-Systems und aller sich darauf beziehenden Gesetze, III. Supplement. Prag 1817.

26. von Bundschuh K. Zusammenstellung derjenigen Diestespflichten [...]. Prag, 1826.

27. von Hietzinger CB. Statistik der Militärgrenze des österreichischen Kaiserthums. Ein Versuch. Vol.1, Wien 1817.

28. The Austrian State Archives (Österreichisches Staatsarchiv], War Archives (Kriegsarchiv), Court War Council (Hofkriegsrat), 1862-8$15-2 / 10$.

29. Thaller L. Povijest medicine u Hrvatskoj Slavoniji od godine 1770. do 1850. Karlovac: Dionička štamparija d.d.,1927.

30. Habek D. Iz povijesti zdravstva Bjelovara. Zavod za znanstvenoistraživački i umjetnički rad u Bjelovaru. Zagreb, Bjelovar: Hrvatska akademija znanosti i umjetnosti, 2015. 